\title{
Inovasi Desain Kemasan Ayam Betutu Sebagai Ikon Oleh - Oleh Khas Bali di Kota Denpasar
}

\author{
NI LUH DESI IN DIANA SARI ${ }^{1}$, NI KETUT PANDE SARJANI ${ }^{2}$ \\ 1,2. Prodi DKV, FSRD, ISI Denpasar \\ Jl. Nusa Indah Denpasar, 80235, Indonesia \\ E-mail : desiindianasari@yahoo.com
}

Tujuan khusus yang ingin dicapai pada tahap ke-dua penelitian ini adalah studi pembuatan desain terdiri dari : 1). Studi grafis kemasan (studi bahan, studi bentuk, studi warna, studi huruf dan teks; 2). Pembuatan alternatif desain kemasan kuliner ayam betutu, 3). Perwujudan prototype alternatif desain kemasan kuliner ayam betutu. Konsep yang dipilih adalah nuansa tradisional Bali dengan mengacu pada kriteria desain menurut Dameria (2014;53), terdiri dari Stands Out (menonjol), Contents (isi), Distinctive (unik), Suitable (sesuai) yang telah ditetapkan pada penelitian tahun pertama. Wujud desain kemasan pada tahapan perancangan dibuat ke dalam dua alternatif desain. Bahan yang digunakan kertas food grade, melalui tiga tahapan yaitu; 1). Tahapan ide 2). Tahapan desain terdiri dari perancangann kemasan, elemen grafis kemasan pada panel display utama (PDU). Kemudian dilanjutkan ke tahap 3). Feasibility Phase yang merupakan tahapan pembuatan prototype menggunakan bahan dan peralatan yang mirip dengan kondisi aktual desain kemasan kuliner Ayam Betutu. Hasil yang diperoleh adalah prototype desain kemasan berbahan dasar kertas untuk mengemas kuliner Ayam Betutu.

Kata kunci : inovasi, desain kemasan, kuliner ayam betutu

\section{Innovation of Ayam Betutu Packaging Design As a Typical Balinese Souvenir Icon in Denpasar City}

\begin{abstract}
Specific objectives to be achieved in this second phase of research is a design study that consists of: 1). researching graphic packaging (material studies, form studies, color studies, study letters and text, 2). Making alternative design culinary packaging for Ayam Betutu, 3). Embodiments prototype alternative design culinary of Ayam Betutu packaging. The selected concept has a traditional Balinese feel, with reference to design criteria consisting of Stands Out, Contents, Distinctive and Suitable that have been established in the first year of research. The form of packaging at the design stage is made into two design alternatives. Material used food grade paper. Two alternative designs are designed through three stages: 1). Stage Idea 2). Stages of design consisting of packaging design, graphic packaging elements on the main display panel. Then proceed to stage 3). Feasibility Phase which is the stage of making prototype using materials and equipment that is similar to the actual condition of culinary packaging design of Ayam Betutu. The results to be obtained is a prototype packaging design to pack the culinary Ayam Betutu.
\end{abstract}

Keywords : innovation, packaging design, ayam betutu culinary

Peer Review : 2 - 19 Januari 2018, Acepted to Publish 22 Januari 2018

\section{PENDAHULUAN}

Keberadaan kuliner Ayam Betutu sebagai salah satu ikon oleh - oleh khas Bali di kota Denpasar saat ini semakin dikenal wisatawan. Hal ini dibuktikan dengan meningkatnya jumlah rumah makan di wilayah kota Denpasar, menyediakan kuliner Ayam Betutu sebagai menu utama. Selain itu kuliner Ayam Betutu juga dapat dijadikan oleh - oleh bagi wisatawan. Namun eksistensi kuliner Ayam Betutu sebagai ikon oleh - oleh khas Bali kepada wisatawan belum didukung dengan desain kemasan yang menarik.

Berdasarkan atas hasil penelitian tahap pertama didapatkan beberapa kategori kemasan yang digunakan untuk mengemas kuliner Ayam Betutu sebagai oleh - oleh, di antaranya kemasan berbahan dasar kertas, plastik dan kemasan berbahan dasar bambu (tradisional). Masing - masing kategori kemasan tersebut terdapat beberapa permasalahan. Seperti kemasan berbahan dasar kertas yang digu- 
nakan beberapa rumah makan Ayam Betutu Khas Gilimanuk, Ayam Betutu Nia, Ayam Betutu Bu Koming, dan Ayam Betutu Rama (Diana Sari, Sarjani,2016;361-364). Permasalahan pertama dilihat dari segi bahan yakni pemakaian karton duplek. Karton duplek merupakan kertas daur ulang sehingga tidak aman untuk mengemas makanan. Karena dalam proses pembuatannya bahan kertas yang digunakan tidak diketahui asal usulnya. Permasalahan kedua, dari segi bentuk kemasan, hanya dibuat berbentuk kotak yang biasa dijual di pasaran. Permasalahan ketiga dilihat dari segi elemen grafis kemasan yang belum digarap optimal. Berdasar permasalahan tersebut maka perlu dilakukan pembenahan desain kemasan kertas dengan mengacu pada kriteria desain terdiri dari; menonjol, konten isi, unik dan sesuai (Dameria, 2014;53-54). Menonjol yang dimaksud disini adalah peranan elemen grafis kemasan sebagai daya tarik visual meliputi; pemilihan warna, huruf, ilustrasi dan layout. Konten isi merupakan informasi yang tertera pada kemasan dan harus secara efektif dan komunikatif memberikan informasi produk yang dikemas. Unik yang dimaksud dilihat dari segi bentuk disesuaikan denga target konsumen. Pada perancangan ini target audiennya adalah wisatawan maka dari itu bentuk kemasan yang dirancang hendaknya memiliki keunikan dari segi bahan dan bentuk. Sesuai meliputi pemilihan bahan yang tidak hanya memenuhi fungsi keindahan melainkan aspek fungsional kemasan yang mampu melindungi produk, dengan harga terjangkau. Rumusan kriteria ini dapat dijadikan acuan dalam merumuskan konsep desain, ide, dan model kemasan (Packaging Design Brief).

Inovasi desain kemasan diperlukan agar kuliner Ayam Betutu layak dibawa wisatawan sebagai oleh - oleh. Selain memenuhi fungsi estetis, desain kemasan hendaknya memiliki fungsi praktis yang mudah dibawa. Kehadiran desain kemasan harus mampu meningkatkan pencitraan suatu daerah dengan menonjolkan berbagai identitas khas yang menjadi daya tarik wisata. Sehingga identitas ini dapat berfungsi sebagai pembeda (diferensiasi) antara suatu daerah dengan daerah lain. Hal ini dilakukan untuk melestarikan kuliner khas daerah agar tetap eksis ditengah hadirnya berbagai kuliner luar yang dapat menggantikan keberadaan kuliner tradisional.

Inovasi kemasan merupakan perubahan secara mencolok yang bisa menggugah kebiasaan konsumen. Peran desainer dalam hal ini sangatlah besar. Sebagai seorang desainer mesti mengerti faktor - faktor teknik berhubungan dengan kemasan dan desain untuk menghindari hasil desain yang tidak dapat diproduksi. Adapun ruang lingkup permasalahan dalam penelitian tahap ke-dua; 1). Bagaimana menciptakan inovasi desain kemasan kuliner ayam betutu sebagai ikon oleh - oleh khas Bali di kota Denpasar ? 2). Bahan dan teknik apa yang digunakan untuk menciptakan inovasi desain kemasan kuliner ayam betutu yang memiliki ciri khas ?

\section{METODE}

Secara garis besar metode yang digunakan dalam proses penciptaan desain kemasan untuk mengemas kuliner Ayam Betutu sebagai ikon oleh - oleh khas Bali tergambar pada proses berikut ini

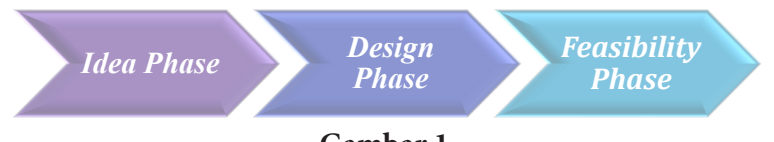

Gambar 1.

Proses Penciptaan Desain Kemasan untuk Mengemas Kuliner Ayam Betutu

Sumber : Julianti, 2014;53

\section{Idea Phase (Tahap Ide)}

Tahap ide merupakan langkah awal yang dilakukan dalam proses penciptaan karya. Tahap ide diawali dengan tahap penemuan gagasan berupa konsep yang dijadikan acuan dalam berkarya. Mengutip pendapat Masri dalam strategi visual (2010:27). Konsep dapat dipahami sebagai dasar pemikiran yang strategis untuk mencapai satu tujuan. Konsep bersifat pemikiran, dan tidak bersifat operasional. Konsep membutuhkan implementasi dan bersifat rencana.

Tahapan ide didapatkan berdasarkan pendapat masyarakat terhadap desain kemasan yang digunakan untuk mengemas kuliner ayam betutu. Berdasarkan pendapat tersebut ide - ide yang terlontar kemudian didiskusikan, disaring dan dipilih ide mana yang sesuai dengan kebutuhan. Pada tahapan ini hal pertama yang dilakukan adalah persiapan berupa pengamatan, pengumpulan informasi dan gagasan melalui metode - metode diantaranya :

\section{Metode Pengumpulan Data}

Metode pengumpulan data dilakukan guna memperoleh data primer dan data sekunder sebagai informasi terkait subyek dan obyek perancangan.

\section{Data Primer}

Data primer diperoleh melalui survey, observasi, dan wawancara terkait dengan objek perancangan dan sumber ide penciptaan.

\section{Data Sekunder}

Data sekunder diperoleh melalui kajian pustaka yang relevan dengan subjek parancangan, yaitu kemasan. 
Data ini digunakan sebagai landasan teoritis untuk menunjang data primer. Selain berupa kajian pustaka data sekunder dapat berupa referensi karya - karya sejenis sebagai acuan dalam proses perancangan untuk menghasilkan solusi pemecahan masalah yang tepat. Target pencapainnya adalah menciptakan kemasan ideal sebagai media untuk mengemas ayam betutu yang dijadikan sebagai ikon oleh - oleh khas Bali kepada wisatawan sebagai target audien.

\section{Metode Mind Map}

Mind Map adalah cara termudah untuk menempatkan informasi ke dalam otak dan mengambil informasi ke luar dari otak. Mind map adalah cara mencatat yang kreatif, efektif, dan secara harfiah akan "memetakan" pikiran - pikiran kita. Sangat sederhana untuk diterapkan dalam proses penciptaan (Buzan, 2005:4).

Mind Map pada penciptaan ini digunakan sebagai langkah awal untuk menggali berbagai sumber ide yang ada di pikiran, kemudian dituangkan dalam catatan - catatan kreatif sebagai upaya melahirkan gagasan ide penciptaan. Metode mind map sangat membantu dalam menemukan gagasan kreatif melalui cara berpikir lateral untuk menemukan keterkaitan antara satu obyek dengan obyek yang lain. Menemukan kemungkinan - kemungkinan yang tak terduga sebelumnya dan sebagai upaya menimimalisir kesalahan.

\section{Metode Identifikasi Data}

Identifikasi data pada proses perancangan ini menggunakan metode $5 \mathrm{~W}+1 \mathrm{H}$ (what, why, who, where, when dan how), merupakan metode yang diterapkan pada bahasa jurnalistik, dengan mengacu pada target audien dari perancangan.

Metode ini digunakan dengan menjawab pertanyaan seputar (what, why, who, where, when dan how), sebagai landasan berfikir desain untuk memecahkan permasalahan terkait dengan perancangan. Menghasilkan solusi - solusi kritis dan kreatif.

\section{Design Phase (Tahapan desain)}

Pada tahap ini, format dan informasi produk sudah ditentukan. Semua informasi yang diperlukan oleh desainer dituangkan dalam Packaging Design Brief. Proses kreatif dalam perancangan media kemasan untuk produk ayam betutu terdiri dari beberapa tahapan diantaranya : 1). Proses Berfikir, 2). Riset dan Analisa, 3). Thumbnails (Layout Kasar), 4. Evaluasi Penyempurnaan.
Semua tahapan proses kreatif diatas senantiasa berpijak pada studi bahan, studi bentuk, studi warna, studi huruf, komposisi/layout dan sintesa untuk menentukan desain terpilih.

\section{Feasibility Phase}

Pada tahap ini komponen kemasan dibuatkan prototype menggunakan bahan dan peralatan yang mirip dengan kondisi aktualnya (Julianti, 2014:53).

\section{Capability Phase}

Pada tahap ini semua komponen kemasan dilakukan tes final. Untuk mengetahui standar kualitas kemasan dan final produk sebelum diproduksi.

\section{PEMBAHASAN}

\section{Perancangan Desain Kemasan}

Perancangan desain kemasan merupakan seluruh kegiatan merancang, memproduksi wadah atau bungkus untuk mengemas produk. Kegiatan ini bertujuan untuk memenuhi fungsi kemasan sebagai fungsi kemudahan fisik, fungsi keamanan, fungsi kemudahan dalam pengelompokkan, penempatan, penyimpanan, fungsi informasi komunikasi dan fungsi marketing (Dupuis\&Silva,2008:106). Perancangan kemasan untuk mengemas kuliner Ayam Betutu senantiasa dilakukan untuk memenuhi fungsi tersebut, dipadukan dengan strategi kreatif sebagai daya tarik untuk menciptakan kemasan yang menarik secara visual terdiri dari bentuk, layout, panel display utama, tipografi, warna, dan ilustrasi.

Desain kemasan yang dipilih dalam perancangan ini adalah desain kemasan sekunder yang diklasifikasikan berdasarkan bahan yang digunakan yaitu desain kemasan terbuat dari kertas. Kemasan sekunder berfungsi mewadahi kemasan primer. Kemasan primer pada perancangan ini menggunakan bahan plastik food grade dengan metode vakum. Kemasan vakum adalah metode pengemasan dengan menghilangkan semua udara dari dalam kemasan sebelum di las. Metode ini dilakukan secara manual atau otomatis menggunakan mesin vakum. Tujuan digunakannya kemasan ini agar aroma dari kuliner Ayam Betutu tetap terjaga, Sehingga daya simpan makanan bisa lebih lama (Julianti, 2017:174). Kemasan kertas kemudian didesain dengan mengacu pada kriteria yang telah dirumuskan pada penelitian tahap pertama, terdiri dari; 1). Stands Out (menonjol), 2). Contents (isi), 3). Distinctive (unik), 4). Suitable (sesuai). Berikut tahapan proses perancangan yang telah dilakukan. 


\section{Tahap Ide}

Pada tahap ide hal - hal penting yang menjadi pertimbangan sebelum merancang desain kemasan dikelompokan kedalam tiga hal yaitu: 1). Memahami karakter produk kuliner Ayam Betutu, fungsi, cara penyajian dan karakter khusus; 2). Memahami konsumen meliputi target market, karakter target market, kebutuhan target market akan kemasan produk, pola komunikasi yang sesuai; 3). Konsep desain meliputi: apa yang ingin dikomunikasikan, citra produk yang ingin dibangun dan cara mengkomunikasikannya lewat kemasan.

\section{Tahap Desain Kemasan Berbahan Kertas}

Desain kemasan berbahan dasar kertas merupakan kemasan sekunder yang digunakan untuk mengemas kemasan primer kuliner Ayam Betutu, berbahan plastik food grade ukuran 18 × $28 \times 3,5 \mathrm{~cm}$, berat produk $1 \mathrm{~kg}$. Cara pengemasan dilakukan menggunakan teknologi vakum bertujuan agar daya simpan bisa lebih lama. Bentuk kemasan sekunder dirancang mengacu pada bentuk produk (Gambar 2) .

Desain kemasan sekunder dibuat berbentuk kotak yang dapat dibuka dan ditutup. Desain ini merupakan pengembangan dari desain kemasan yang digunakan sebelumnya, dibuat berbentuk kotak lipat tanpa menggunakan lem dan staples. Ukuran dummy kemasan kotak yang dibuat pertama berukuran 23 x 18 x $6 \mathrm{~cm}$, berbahan dasar karton 210 gr. Setelah dicoba untuk mengemas kemasan primer ternyata hasilnya kekecilan, tahapan selanjutnya dilakukan perubahan ukuran menjadi $24 \times 19 \times 6 \mathrm{~cm}$ dan menggunakan bahan art paper 260 gr. Setelah diuji coba untuk mengemas kemasan primer hasilnya kebesaran dan ukurannya kembali direvisi menjadi $23,5 \times 18,5 \times 6 \mathrm{~cm}$, bahan yang digunakan art paper 310 gr. Penggunaan kertas art paper ternyata kurang

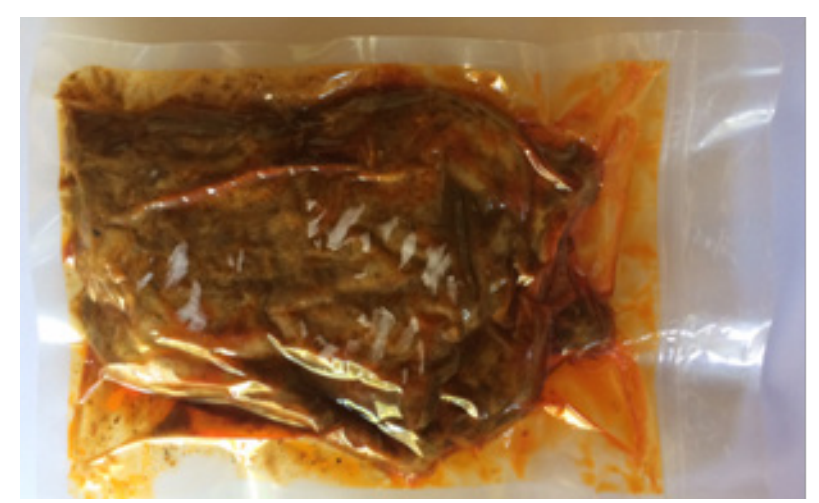

Gambar 2.

Kemasan Primer Kuliner Ayam Betutu Denpasar Sumber : Dokumen Penulis, 2017 kuat digunakan untuk mengemas produk dengan berat $1 \mathrm{~kg}$, untuk itu perlu dilakukan perbaikan kembali dengan mengganti bahan kemasan menggunakan kertas ivory 360 gr. Hasilnya dummy desain kemasan dengan ukuran $23,5 \times 18,5 \times 6 \mathrm{~cm}$, bahan kertas ivory 360 gr dapat digunakan dan dilanjutkan ke tahap pembuatan outline kemasan menggunakan software komputer.

\section{Desain Elemen Grafis Kemasan (Panel Display Utama)}

Panel display utama merupakan area yang terdapat dibagian depan desain kemasan dikhususkan untuk menempatkan identitas merek dan elemen - elemen komunikasi utama. Elemen - elemen pada PDU yang diperlukan pada umumnya meliputi : tanda merek, nama merek, nama produk, keterangan komposisi, (ingredient), berat bersih, informasi nilai gizi, tanggal kadaluarsa, peringatan bahaya, arahan penggunaan, dosis, intruksi, ragam, barcode. Sedangkan elemen yang diatur dengan desain meliputi : warna, citra, huruf, ilustrasi, sarana grafis, foto (noninformasi), simbol (noninformasi), ikon, dan hirarki visual (Klimchuck dan Krasovec,2007:84,85).

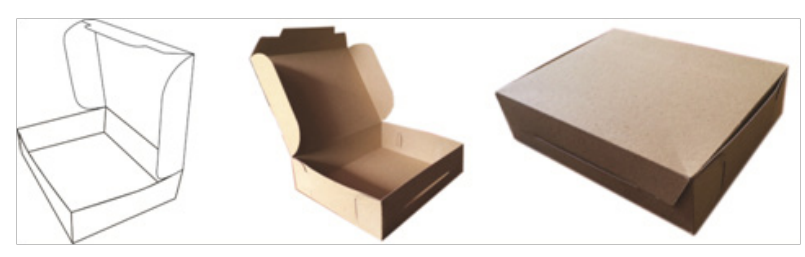

Gambar 3.

Tahapan Pembuatan Dummy Desain Kemasan Sekunder Sumber : Dokumen Penulis, 2017
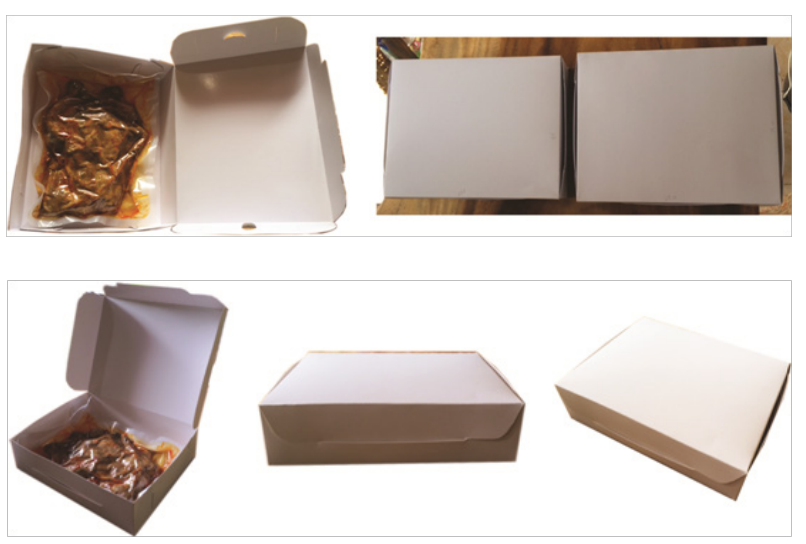

Gambar 4,5.

Tahapan Pembuatan Dummy Desain Kemasan Sekunder Sumber : Dokumen Penulis, 2017 


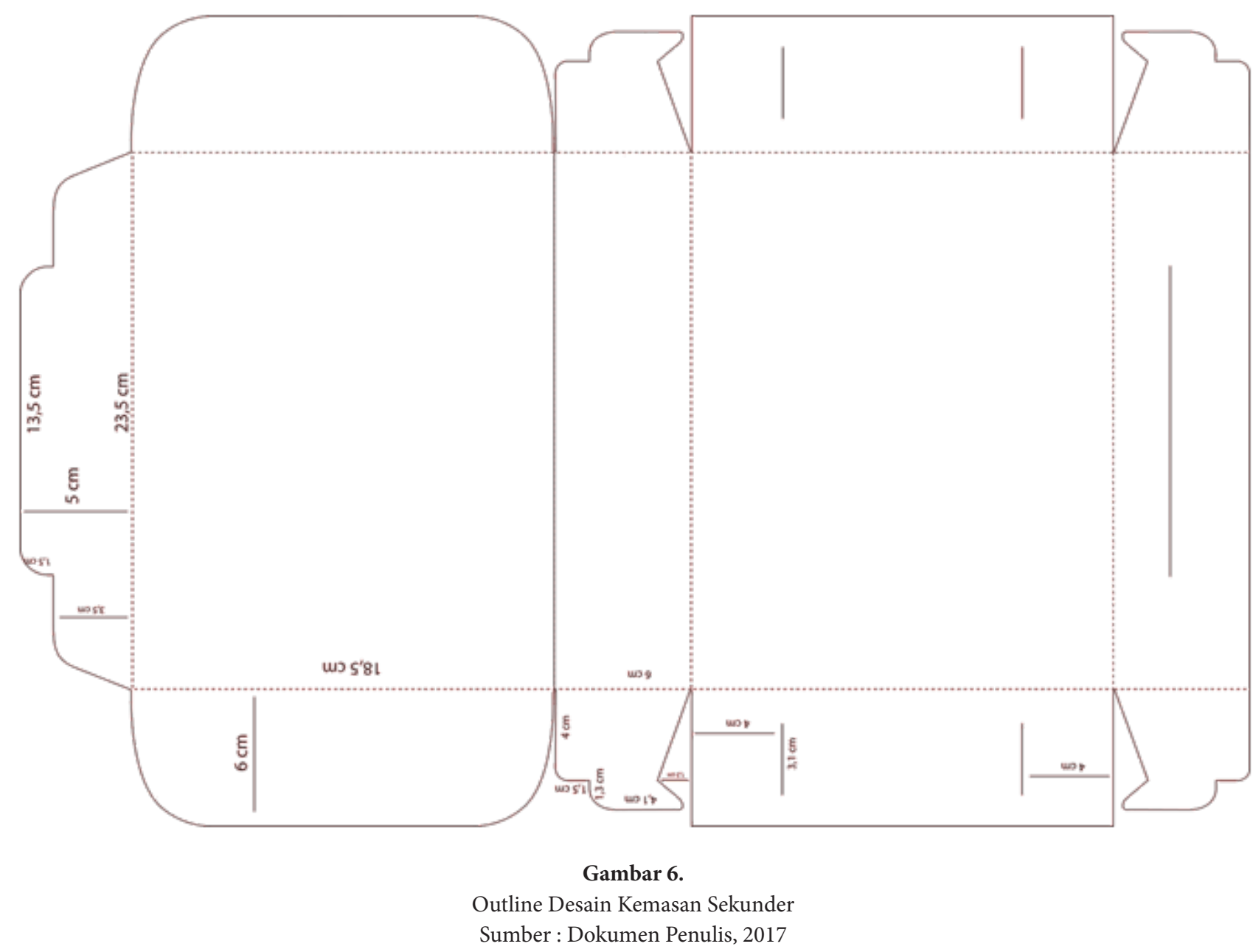

\section{Penciptaan Merek}

Penciptaan merek merupakan hal pertama yang dilakukan sebagai upaya untuk mengkomunikasikan kuliner Ayam Betutu kepada target audien. Pada perancangan ini tahapan penciptaan merek meliputi nama merek dan logo sebagai identitas merek.

Nama merek adalah elemen tunggal yang paling penting dalam perancangan kemasan. Nama merek berperan sebagai alat identifikasi merek dan produk. Mendukung jaminan merek, dan idealnya sebagai alat impresi kepada target audien dalam menciptakan kesan berbeda, dan mudah diingat. Sebagai pijakan dasar dalam pembangunan ekuitas merek di benak target audien (Klimchuck\&Krasovec,2007:188).

Penciptaan nama menjadi langkah utama dan sangat penting dalam mengembangkan suatu merek atau produk baru. Tugas menemukan nama produk adalah komponen serius dalam tugas desain kemasan. Penciptaan nama dimulai dari membuat daftar kata - kata yang diasosiasikan dengan produk dan kepribadian- nya. Mengkombinasikan kata dan huruf dapat menghasilkan kata - kata baru. Nama merek hendaknya harus merefleksikan posisi produk, dan mudah diingat konsumen (Klimchuck\&Krasovec(2007:189).

Pada perancangan desain kemasan untuk mengemas kuliner Ayam Betutu, Nama merek yang digunakan sebagai identitas kuliner Ayam Betutu di kota Denpasar adalah "Ayam Betutu Denpasar". Pemberian nama ini dimaksudkan untuk mewakili keseluruhan rumah makan yang menyediakan kuliner Ayam Betutu di wilayah Denpasar. Sedangkan untuk merek dari masing - masing produsen dapat dicantumkan pada informasi diproduksi oleh di panel display utama. Setelah penciptaan nama merek dilanjutkan ketahap perancangan desain logo sebagai identitas merek.

\section{Logo sebagai identitas merek}

Jenis logo yang digunakan untuk membuat identitas merek "Ayam Betutu Denpasar" dikategorikan kedalam jenis logotype, diartikan sebagai tulisan nama entitas yang didesain menggunakan jenis huruf tertentu. Logotype pada perancangan ini berfungsi se- 
bagai identitas yang membedakan produk satu dengan yang lainnya, tanda kepemilikan, tanda jaminan kualitas, dan mencegah peniruan atau pembajakan (Rustan, 2009:13). Berdasarkan anatominya logo Ayam Betutu Denpasar dikategorikan kedalam jenis logo lettermark didominasi oleh tulisan, mengandung kata dan huruf (Rustan, 2009:21).

Tahapan perancangan dilakukan dengan mengeksplorasi tipografi yang dapat mewakili identitas merek dipilih jenis font Goudy Sans Medium Italic BT. Jenis huruf ini mengkomunikasikan karakteristik Bali, terkenal akan keelokan dan keindahan seni budayanya yang ekspresif, dinamis dan tidak terkesan kaku. Pemilihan warna merah dan kuning keemasan mewakili identitas warna Bali yang identik dengan warna tersebut, sesuai, mudah dikenali, dan unik bagi merek. Jenis huruf ini juga mudah diterapkan, dibaca dalam ukuran, format, warna dan cetakan yang berbeda. Berikut tiga alternatif desain logo yang telah dirancang kemudian dipilih satu untuk di layout pada panel display utama. Pada perancangan ini alternatif desain logo terpilih adalah desain logo alternatif 3 seperti nampak pada gambar dibawah ini, dengan pertimbangan bahwa desain logotype terpilih ketika diaplikasikan pada panel display utama lebih jelas terlihat dan belum ada yang menggunakan sebelumnya.

\section{Perancangan Ilustrasi Kemasan}

Ilustrasi sebagai elemen estetis pada desain kemasan kuliner Ayam Betutu Denpasar menggunakan ilustrasi fotografi (gambar 8), menampilkan produk kuliner Ayam Betutu. Penggunaan ilustrasi ini dimaksudkan untuk memberikan informasi kepada konsumen mengenai isi produk dan daya tarik. Selain foto produk ilustrasi bahan - bahan yang digunakan untuk membuat kuliner Ayam Betutu Denpasar juga ditampilkan sebagai elemen estetis kemasan menggunakan teknik ilustrasi digital. Ikon bunga Jempiring sebagai maskot kota Denpasar dijadikan sebagai elemen estetis kemasan untuk menginformasikan bahwa produk ini adalah oleh - oleh khas Bali di kota Denpasar. Selain itu ilustrasi Upih (pelepah pinang) juga digunakan sebagai elemen estetis, dimaksudkan untuk memberikan citarasa tradisional khas Bali yang dihadirkan dengan sentuhan moderen. Kemasan bernahan dasar kertas ilustrasi pada panel display utama langsung dicantumkan pada bentuk kemasan.

\section{Layout Panel Display Utama (PDU) Desain Ke- masan Berbahan Dasar Kertas}

Tahapan perancangan panel display utama untuk desain kemasan berbahan dasar kertas dipilih bentuk desain kemasan alternatif dua dan tiga, oleh karena desain kemasan alternatif satu, ukurannya tidak memungkinkan untuk diwujudkan dan tidak ekonomis dilihat dari segi ukuran dan bentuknya.

Daya tarik utama tediri dari nama merek, ilustrasi, warna, tipografi dan layout pada desain kemasan kertas alternatif dua dan tiga, terdapat pada PDU. Dilayout menggunakan prinsip keseimbangan simetris. Antara satu bagian dengan bagian lainnya terlihat seimbang. Sedangkan urutan keterbacaan informasi menggunakan prinsip layout membentuk sequencel urutan seperti huruf I, bertujuan untuk memudahkan konsumen membaca urutan informasi yang disampaikan. Sequence/urutan seperti huruf I dapat mempengaruhi kecenderungan target audien dalam membaca informasi yang diurutkan dari atas kebawah, sehingga informasi yang disampaikan dapat terbaca secara sitematis. Gambar 9, menunjukkan elemen grafis pada PDU desain kemasan kertas yang telah dilayout .

\section{Ayam Betutu Denpasar Becuturya Kota Deppasar Desain Logo Altematif 1}

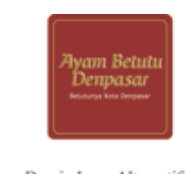

Desain Logo Alternatif 2

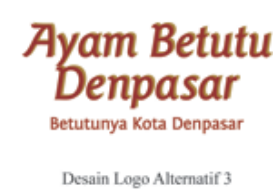

Gambar 7.

Alternatif Desain Logo Ayam Betutu Denpasar Sumber : Dokumen Penulis, 2017
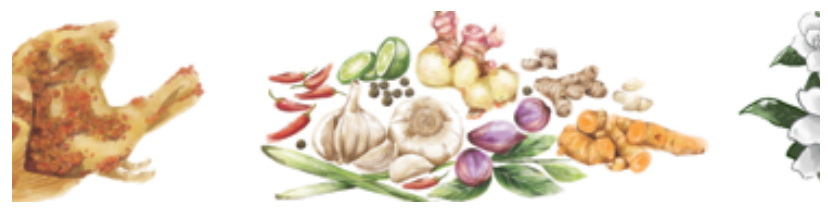

Gambar 8.

Ilustrasi Sebagai Elemen Estetis Pada Desain Kemasan Kuliner Ayam Betutu Denpasar

Sumber : Dokumen Penulis, 2017 


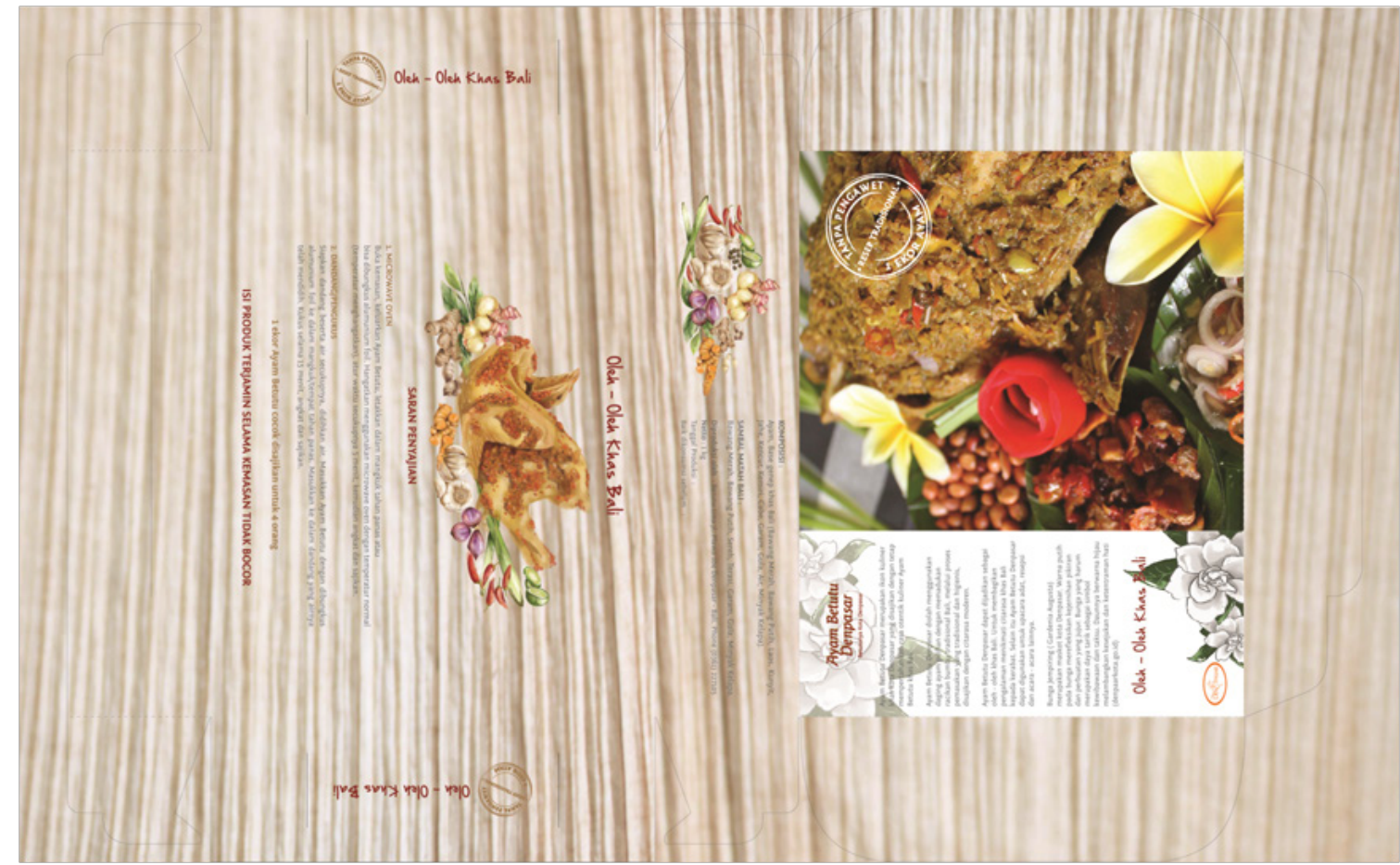

Gambar 9.

Layout PDU Desain Kemasan Sekunder Berbahan Dasar Kertas Sumber : Dokumen Penulis, 2017

\section{Feasibility Phase}

Feasibility Phase merupakan tahapan pembuatan prototype menggunakan bahan dan peralatan yang mirip dengan kondisi aktual desain kemasan kuliner Ayam Betutu. Pada tahap Feasibility Phase alternatif bentuk desain kemasan terpilih yang telah didesain kemudian diwujudkan bentuk aslinya dengan skala 1:1. Berikut uraian tahapan Feasibility Phase desain kemasan kuliner Ayam Betutu yang menggunakan bahan kertas

Desain kemasan berbahan dasar kertas

Ukuran $: 23,5 \times 18,5 \times 6 \mathrm{~cm}$

Bahan

: Kertas Ivory 360 gr

Teknik cetak : Digital printing

Finishing : Laminasi doff
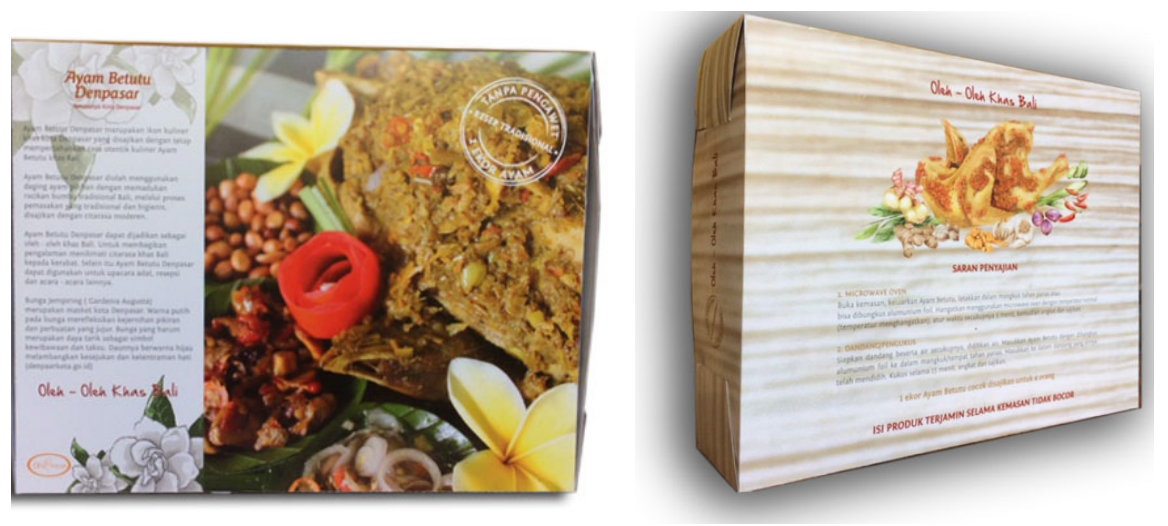

Gambar 10.

Dummy Desain Kemasan Sekunder Berbahan Dasar Kertas Tampak Depan dan Belakang Sumber : Dokumen Penulis, 2017 

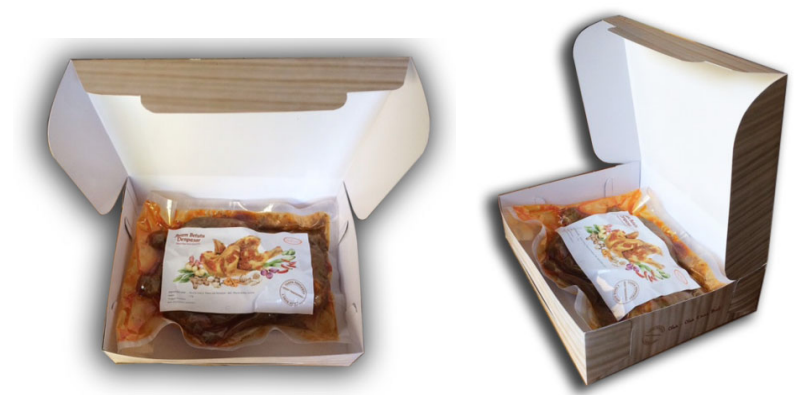

Gambar 11.

Dummy Desain Kemasan Sekunder Berbahan Dasar Kertas Tampak Bagian Dalam

Sumber : Dokumen Penulis, 2017

\section{SIMPULAN}

Menciptakan inovasi desain kemasan kuliner Ayam Betutu sebagai ikon oleh - oleh khas Bali di kota Denpasar dilakukan melalui beberapa tahapan diantaranya :

Tahap ide perancangan dimulai dengan melakukan mind map terhadap beberapa kemungkinan ide yang dapat diwujudkan. Dari hasil mind map tersebut diperoleh bentuk - bentuk kemasan yang selanjutnya dituangkan kedalam bentuk sketsa, kemudian diwujudkan dalam bentuk dummy (wujud riil) sebelum dilanjutkan ketahap pembuatan soft copy menggunakan program komputer.

Pada tahap ide hal - hal penting yang menjadi pertimbangan sebelum merancang desain kemasan dikelompokan kedalam tiga hal yaitu: 1). Memahami karakter produk kuliner Ayam Betutu, fungsi, cara penyajian dan karakter khusus; 2). Memahami konsumen meliputi target market, karakter target market, kebutuhan target market akan kemasan produk, pola komunikasi yang sesuai; 3). Konsep desain meliputi: apa yang ingin dikomunikasikan, citra produk yang ingin dibangun dan cara mengkomunikasikannya lewat kemasan.

Berdasarkan pertimbangan diatas, data tersebut kemudian diidentifikasi menggunakan metode $5 \mathrm{~W}$ $+1 \mathrm{H}$ dengan menjawab pertanyaan seputar (what, why, who, where, when dan how) sebagai landasan berpikir desain untuk memecahkan permasalahan terkait dengan perancangan, sehingga mampu menghasilkan solusi kritis, kreatif dan dapat diwujudkan. Pada tahap desain hal yang dilakukan pertama adalah membuat prototype kemasan yang diklsifikasikan berdasarkan bahan yang digunakan. Bahan tersebut terdiri dari bahan dasar kertas dan bahan dasar nat-

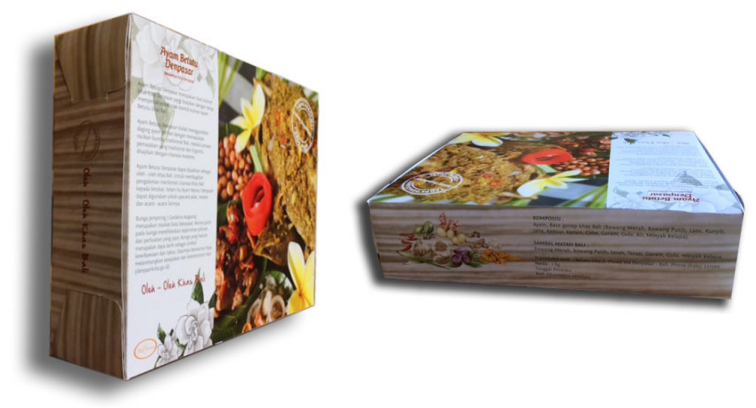

Gambar 12.

Dummy Desain Kemasan Sekunder Berbahan Dasar Kertas Tampak samping

Sumber : Dokumen Penulis, 2017

ural/alam. Kedua bahan ini kemudian dibuatkan alternatif desain terdiri dari lima, tiga alternatif desain kemasan berbahan dasar kertas dan dua alternatif desain berbahan dasar natural/alam.

Setelah selesai pembuatan alternatif desain dilanjutkan ketahapan pembuatan elemen visual grafis kemasan terdiri dari nama merek, desain logo sebagai identitas merek dan PDU (Panel Display Utama) memuat informasi dan elemen estetis kemasan terdiri dari logo, ilustrasi, warna, tipografi dan layout. Nama merek dari produk ini adalah "Ayam Betutu Denpsar" kemudian nama merek ini dibuatkan desain logo sebagai identitas yang dicantumkan pada PDU kemasan. PDU untuk kemasan berbahan kertas dan kemasan berbahan dasar natural/alam dibuat dalam bentuk berbeda. Label dan hang tag untuk kemasan berbahan dasar natural/alam. Sedangkan pada kemasan berbahan dasar kertas PDU langsung di desain pada outline kemasan menggunakan program komputer.

Feasibility Phase merupakan tahapan pembuatan prototype menggunakan bahan dan peralatan yang mirip dengan kondisi aktual desain kemasan kuliner Ayam Betutu. Pada tahap Feasibility Phase alternatif bentuk desain kemasan terpilih yang telah didesain kemudian diwujudkan bentuk aslinya dengan skala $1: 1$.

Bahan dan teknik yang digunakan untuk menciptakan inovasi desain kemasan kuliner merek "Ayam Betutu Denpasar" adalah kemasan berbahan dasar kertas menggunakan kertas jenis ivory 360gr, dibuat dengan teknik karton lipat tanpa menggunakan lem dan staples. Bahan yang dipilih merupakan bahan food grade yang aman untuk mengemas produk makanan sehingga tidak mengkontaminasi produk. 


\section{DAFTAR RUJUKAN}

Buzan, Tony. The Ultimate Book of Mind Maps atau Buku Pintar Mind Map, terjemahan Susi Purwoko (2005), Gramedia Pustaka Utama, Jakarta.

Dameria, Anne. (2014), Packaging Hand Book, Where Creative Ideas Become Reality, Link \& Match Graphic, Jakarta.

Desi In Diana Sari, N., \& Pande Sarjani, N. (2017). Characteristics On Culinary Packaging Design Of Ayam Betutu In Denpasar.MUDRA, 31(3). Retrieved from http://jurnal.isi-dps.ac.id/index.php/mudra/article/view/52/28

DuPuis, Steven \& Silva John. (2008), Package Design Work Book, Rockport Publishers, Inc, USA

Julianti, Sri. (2017), A Practical Guide To FlexiblePackaging, Material, Teknologi dan Aplikasi, PT. Gramedia Pustaka Utama, Jakarta.

Klimchuk, Rosner \& Krasovec. A. Sandra. (2006), Packaging Design Successful

Product Branding From Concept to Shelf atau Desain Kemasan Perencanaan

Merek Produk yang Berhasil Mulai dari Konsep Sampai Penjualan, terjemahan Bob Sabran. (2007), Erlangga, Jakarta.

Masri, Andri. (2010), Strategi Visual, Jalasutra, Yogyakarta

Rustan, Surianto. (2009), Mendesain Logo, PT. Gramedia, Jakarta 